\title{
20 South Africa's response to COVID-19
}

\section{The multilevel government dynamic}

\author{
Nico Steytler and Jaap De Visser
}

\subsection{Introduction}

When the COVID-19 pandemic reached South Africa in March 2020, the country already faced severe social, economic, and political difficulties. Socially, half of the population was poor, many in the urban areas living in informal settlements, and with an unemployment rate of 30 percent. The country's economy was not growing and was in recession. Politically, the divisions in the country, between black and white, poor and rich, rural and urban, were stark. South Africa's multilevel system of government - the national government, provinces, and municipalities - was struggling to meet these difficulties. The COVID-19 pandemic made these difficulties more intense, resulting, among other things, in a more centralized system of multilevel government (Table 20.1).

\subsection{COVID-19 in South Africa}

South Africa recorded its first Coronavirus infection on 5 March 2020. Since then, the number of infections has increased steadily, reaching a peak by June/July, before declining significantly over the next three months, but by the end of October, the infection rate spiked dramatically in some parts of the country as a second wave seemingly gathered moment.

By 31 July, South Africa placed among the top five in the world in terms of confirmed COVID-19 infections with a total of 493,183 infections (Department of Health 31 July 2020). However, the number of COVID-19-related deaths remained significantly low $(8,005)$ compared to other countries in the top five. Gauteng and the Western Cape, the two most urbanized provinces, took turns in being the epicenter of the virus. Other provinces such as North West and Northern Cape, which are generally sparsely populated, experienced low levels of infections and deaths.

Table 20.1 Key Statistics on COVID-19 in South Africa as of 10 January 2021

\begin{tabular}{lllll}
\hline $\begin{array}{l}\text { Cumulative } \\
\text { Cases }\end{array}$ & $\begin{array}{l}\text { Cumulative Cases per } \\
100,000 \text { Population }\end{array}$ & $\begin{array}{l}\text { Cumulative } \\
\text { Deaths }\end{array}$ & $\begin{array}{l}\text { Cumulative Deaths per } \\
100,000 \text { Population }\end{array}$ & $\begin{array}{l}\text { Case-Fatality } \\
\text { Percentage }\end{array}$ \\
\hline $1,214,176$ & $2,047.2$ & 32,824 & 55.3 & 2.7
\end{tabular}

Source: World Health Organization Weekly epidemiological update - 12 January 2021. Geneva: WHO, 2021. Available from https://www.who.int/publications/m/item/weekly-epidemiological-update 
As of 30 September 2020, South Africa was at the lowest level of its five-level scale of restrictions (Level 1), with a total of 674,339 COVID-19 confirmed cases and 16,734 COVID-19-related deaths. By the end of December 2020, on the back of a second wave, the cumulative total of COVID-19 cases identified stood at 1,057,161, a recovery rate of 83 percent and 28,469 fatalities (Department of Health 31 December 2020). These official fatality figures are, however, an undercount. The South African Medical Research Council reported 110,000 excess deaths in South Africa since May 2020 to mid-January 2021, measuring the total number of fatalities from natural causes compared with the expected death rate in a "normal" year. The vast majority of these deaths, it suspects, are linked to COVID-19. And the end of the second wave is still far off, so too, is the economic and social recovery. Both the international and domestic economies have shrunk. The forecast for South Africa is that the Gross Domestic Product (GDP) for 2020 will shrink by more than 8 percent, causing unemployment to reach 40 percent. A fiscal crunch is already experienced; due to the recession, less revenue will be collected to meet increased expenditure in health, social, and economic assistance.

\subsection{COVID-19 pandemic and South Africa's federal arrangements}

\subsubsection{General features}

South Africa has a national government, 9 provinces, and 257 municipalities. The provincial and local spheres are constitutionally entrenched, with their powers listed in the Constitution. Provinces and municipalities have their own, locally elected, provincial legislatures, and municipal councils are headed by indirectly elected Premiers and Mayors, respectively.

Provinces are responsible for big social functions such as public health, housing, primary, and secondary education, and, importantly, disaster management. They share these functions with the national government, which is also responsible for all residual functions, such as international relations, policing, and the judiciary. The national government collects the vast majority of taxes, such as income, corporate, and value-added tax and distributes this annually across the three levels of government. Municipalities are responsible for the delivery of basic services, such as water, sanitation, waste management, roads, and electricity.

Provinces largely confine themselves to implementing national legislation and are almost entirely reliant on transfers from the national government (Khumalo, Mahabir and Dawood 2015). Together with a number of other design features, this makes South Africa a hybrid federal state, encompassing a strong national government, relatively 'weak' provinces, and a mix of strong cities and weak rural municipalities (Steytler 2013).

\subsubsection{National government's response}

The national government declared a national state of disaster on 15 March 2020 and on 27 March 2020 imposed one of the harshest lockdown regimes globally. It is important to note that a declaration of a 'national state of disaster' in terms of the Disaster Management Act of 2002 did not require Parliamentary approval, which a declaration of a state of emergency would have. The declaration of a national state 


\section{2}

of disaster was informed by concerns about high levels of co-morbidity, poverty, and inequality, South Africa's many informal and densely populated settlements and its fragile public health system. The lockdown regime included a strict stay-at-home order, a ban on all gatherings, closure of all external borders and ports, a ban on travel across provincial and municipal boundaries, a closure of the entire economy barring the trade in essential goods and services and even a ban on the sale of alcohol and tobacco. The South African Police Services, municipal law enforcement officers, and even the South African National Defense Force were deployed to enforce the lockdown rules. This was accompanied by a raft of national regulations, determining detailed regimes per sector such as health, education, transport, trade, and home affairs.

The national government also issued a specific set of directions to provincial and local governments. Both municipalities and provinces were instructed to develop COVID-19 Response Plans and establish special disaster management structures (see also below). Municipalities were also instructed to provide emergency water services, identify infection hotspots, and quarantine sites, sanitize public places, monitor social gatherings, and funerals and ensure community awareness.

After five weeks of the 'hard lockdown,' the national government announced a 'risk adjusted strategy' to be implemented from 1 May 2020. This strategy introduced differentiation in two important ways: first different 'alert levels,' ranging from the most severe 'level five' to the most relaxed 'level one,' and second, a place-based approach with possible variations in the severity of the restrictions between provinces and districts. This enabled the national government to determine a different alert level for each province and each district but was not used initially. As the overriding concern was solidarity and manageability, the government shied back from differentiating between provinces and districts. However, in early December 2020, when the second wave manifested itself in certain 'hotspots' - in municipalities along the Western Cape's south coast (the Garden Route) and the Nelson Mandela Bay Metropolitan municipality, stricter rules were imposed on those municipalities only. On 28 December 2020, the government imposed a ban on all gatherings, a curfew (9 PM to 4 AM), a ban on alcohol sales, and closed all beaches, fearing super-spreader events on old year's eve.

South Africa's response to the outbreak was quick, robust, and comprehensive. At first, the restrictions enjoyed broad-based support, in large part due to the re-assuring but realistic and science-based communication of the President and the national Minister of Health. However, the lockdown had a devastating impact on food security, the livelihoods of the marginalized and excluded as well as, essentially, the economy as a whole.

Three weeks into the national lockdown, a social relief and economic stimulus package of R500 billion was announced, totaling 7 percent of the GDP, which is the largest percentage on the continent. It included credit guarantees, support for small businesses, income support (mainly tax measures), and wage protection (through the unemployment insurance fund). Support was also provided to vulnerable households in the form of top-ups to existing grants (such as the Child Support Grant) and emergency food relief. This provided much-needed relief for those hit hardest by the crisis. All of these measures were implemented by the national government.

The package also included an additional R20 billion for health, which was channeled to provinces to augment provincial health budgets for treatment, testing, contact tracing, and the procurement of personal protective equipment (PPE). A further 
R20 billion were set aside for local government to assist them with the additional services as well as their loss of revenue. This was important relief for municipalities and a result of successful lobbying by organized local government.

The social relief and economic stimulus package tells the story of South Africa's centralized response to the crisis. All in all, only R40 billion of the R500 billion were channeled through subnational governments with the remainder administered by national government.

\subsubsection{Provinces' role}

South Africa' nine provincial governments played a key role in fighting the pandemic, although it was limited to assisting national government with the implementation of the national strategy. Provincial governments did not announce, let alone legislate, COVID-19 strategies and/or rules that deviated from the essence of the national approach. This was true to the centralized nature of South Africa's hybrid federal system.

The division of responsibilities with regard to the competency 'disaster management,' at the heart of the management of the pandemic, is a case in point. The Constitution in schedule 4 provides that it is a concurrent power, which means that both national and provincial governments may legislate on it. Conflicts are ultimately resolved by the Constitutional Court. So far, only the national government has adopted a national Disaster Management Act in 2002 (the basis for the current state of disaster and the lockdown regime). Provinces implement this Act as none of them have adopted their own. A key factor is that eight of the nine provinces are controlled by the same African National Congress that controls the national government. Furthermore, as mentioned earlier, provinces rely on national funding. All in all, the legal, political, and financial reality is that the national government managed the disaster, assisted by provinces.

This did not mean that provinces were insignificant. The greatest provincial effort to combat COVID-19 was in the provincial health system. Provincial health departments provided primary and secondary health care. They monitored infection rates, rolled out testing, and screening, conducted contact tracing, raised awareness, equipped provincial hospitals, and treated those who are hospitalized. Second, provincial governments were instrumental in overseeing the implementation of the national strategy to close and re-open public schools. Provinces were also critical in monitoring and supporting municipalities, mainly by working through provincial and district disaster management structures (see below).

When the crisis hit, the national and provincial governments were in their first month of the financial year, which commenced on 1 April. These budget cycles have largely remained intact. The first additional cash injection of R20 billion for increased provincial health spending was appropriated in a special adjustment budget in June, but it came with a slight reduction in the provincial equitable share.

An important question was whether the multilevel nature of South Africa's system of government aided the fight against the pandemic or whether it hampered it. The answer is neither an unequivocal yes nor a definitive no. The relevance of provinces (and local governments) came to the fore in government's 'risk adjusted strategy,' which enabled differentiation across provinces, depending on the infection rate. Indeed, the infection rates differed vastly between provinces. Rural provinces such as 


\section{4}

Nico Steytler and Jaap De Visser

the Northern Cape and Limpopo had low infection rates in comparison with the more urbanized provinces, namely the Western Cape, Gauteng, and KwaZulu-Natal. However, this differentiated strategy to combat the virus was never implemented, thus not taking advantage of the multilevel government system and differentiation between provinces and districts. Provinces were able to innovate and distinguish themselves within the national framework. The Western Cape government, for example, adopted a strategy to actively 'chase' infections by aggressively testing in hotspots, a strategy that yielded higher statistics but assisted in managing the pandemic. On the other hand, some of the national government's efforts to contain the spread of the virus were stumbling over weaknesses in provincial administration. For example, the Eastern Cape government is notorious for its weak provincial administration and debilitating political infighting. Its infection rate was high for a rural province, and there was palpable tension between the national government and the Eastern Cape provincial government over the provincial government's inability to contain the virus.

Provinces have generally been loyal partners of the national government in managing the national state disaster. Certainly, during the first five weeks, provincial governments - even the opposition-controlled Western Cape, cooperated, did their lobbying behind the scenes and avoided overt intergovernmental disputes. However, as the economic contraction spiraled and the devastating impact of the lockdown on livelihoods became more and more evident, cracks appeared in the united nationalprovincial front. As usual, the opposition-controlled Western Cape government was where most of the pushback came from. For example, the Western Cape re-introduced school feeding schemes, a critical lifeline for vulnerable children that the national government had cancelled. It was also openly criticizing lockdown rules and is 'petitioning' the national government for a relaxation to protect its key industries.

\subsubsection{Local government's role}

Municipalities, already facing tremendous financial and governance challenges, suddenly saw their responsibilities increase and their funding eroded with the onset of COVID-19 (De Visser and Chigwata 2020). Some of their existing mandates suddenly intensified. For example, municipal law enforcement officers, ordinarily focused on traffic control, by-laws, and crime prevention, were enlisted to help enforce the national lockdown. Municipalities had to work on water relief measures to ensure hygiene and sanitize public places such as public transport facilities. When the national government gave approximately 19,000 water tanks to provide underserviced areas with (free) water, municipalities had to now ensure that the tanks remained filled. When national government devised a scheme to exempt informal food traders from the general prohibition on street trading, municipalities were enlisted to issue temporary permits. While these functions generally fell within the remit of municipalities, new responsibilities were also loaded on local government. For example, many municipalities had to organize basic shelter and food for the homeless in order to ensure their social distancing. When the lockdown prevented millions from earning an income food relief became necessary. The national government manages the social welfare system, including emergency food relief. However, municipalities had to assist with the identification of beneficiaries and sometimes by establishing their own food relief schemes. 
As national revenue declined, the transfers to local government were consequently also reduced. Because municipalities, on average, are responsible for raising 70 percent of their revenue, the financial impact of the lockdown was immediate. They rely on households and businesses paying property taxes and fees for municipal services. An immediate reduction in payments inevitably followed and is likely to endure as the continuing economic crisis reduces households' and businesses' ability to pay. Municipalities were also reluctant to use their main credit control mechanism (disconnecting electricity) during these times. A few municipalities even responded to the economic hardship by announcing 'payment holidays,' permitting those hardest-hit by the crisis to defer the payment of municipal bills. Municipalities in any event already provided free basic services to the indigent, the numbers of whom have grown substantially during 2020; they had to budget more for free basic services as the lockdown has forced many more people into poverty.

The financial year for municipalities starts annually on $1 \mathrm{July}$, so budget preparations had already started in earnest when the pandemic struck. The disaster management regulations instructed municipalities to prioritize COVID-19 related spending in their upcoming budgets. They were also given a once-off power to pass an additional adjustments budget, thereby changing the priorities of the 2019/2020 financial year. Not many municipalities have made use of this, given the fact that the lockdown period coincided with preparations for their regular budget anyway.

\subsection{Inter-governmental structures}

The crisis intensified the need for collaboration between national, provincial, and local governments. At a national level, the President established a National Coronavirus Command Council (NCCC), comprising a selection of national Ministers. A few weeks into the national state of disaster, it became clear that, in effect, the NCCC was the key decision-maker. All executive measures (including the regulations to govern the lockdown) passed through the NCCC before they were officially passed by the full Cabinet and the relevant Ministries. The role of the NCCC was challenged in court, but the latter found that it was a legitimate cabinet committee.

The NCCC was not used for national-provincial cooperation, but the President's Coordinating Council (PCC), South Africa's apex intergovernmental coordination body, was. This body is provided for in law and brings together the President, key Ministers, nine Premiers, and a representative of organized local government. Ordinarily, it meets a few times each year. However, at the early phases of the crisis, it met weekly and coordinated the national-provincial response at a political level. Sector IGR forums (so-called MinMECS) also operated in the fields of health, education, and local government. A hands-on sectoral IGR forum was the Council of Education Ministers, which brings together the national minister and his or her provincial counterparts in a statutory body. It was very active and cooperative during 2020 seeking to save the school year from the ravages of the pandemic.

Intergovernmental coordinating platforms also existed at provincial and local levels. Provincial governments convened provincial command councils, largely mirroring the national structure. Local government was sometimes invited to their meetings. At an administrative level, there was close interaction between local and provincial governments, mainly through Joint Operating Centres (JOCs), established in terms of the Disaster Management Act at both provincial and district level. At the height of the 
crisis, they met almost daily, and the general sentiment was that they are functioning reasonably well.

During the early phase of the state of disaster, there was close collaboration between the national government and the nine provincial Premiers. However, six weeks into the lockdown, some provinces were starting to resent the highly centralized management of the disaster. In developing lockdown regulations, the national government gave provinces the same rights as citizens, namely, to send in their comments on drafts. Concerns in respect of the power of the NCCC were mounting. There was no provincial or local government representation on the NCCC with government rather relying on the PCC for high-level consultation with provinces. This is despite the fact that the Disaster Management Act actually calls for a dedicated intergovernmental committee of national, provincial, and local representatives to coordinate disaster management among the spheres of government.

\subsection{Conclusion}

Although the key policy areas concerning combating the Covid-19 pandemic were concurrent responsibilities - health, disaster management, education, and social welfare - calling for cooperation and coordination, during the first wave of the pandemic, the response was decidedly centralized. Instead of using existing intergovernmental relations structures as the main coordinating vehicles, the national government concentrated power in an informal cabinet committee, the National Coronavirus Command Centre, with no provincial or local government presence on them. In its shadow operated the existing IGR forums - the President's Coordinated Councils and sector IGR forums dealing with health and education.

Although provided for in the Disaster Regulations, there was no provincial differentiation on key issues such as the lockdown rules and the key tenets of the public health response. Provinces played a crucial role in implementing, but not in designing, the response to the disaster. Given that national government collects all major revenue, the fiscal response was also designed and paid for by the national government, with little input from provinces. However, the performance of provinces has been highly uneven, some did well while others struggled to provide the necessary services. Local government has been confronted with additional mandates and the prospect of drastically reduced revenue with national government promising some relief. Some municipalities managed well in delivering these services, while others were hamstrung in their performance by maladministration and corruption.

Intergovernmental relations have worked reasonably well to address implementation challenges, but not as a mechanism to co-design policy or regulation. Contestation over policy was limited as the ruling party controlled most provinces and municipalities. It was only the Western Cape and the City of Cape Town, in the hands of the main opposition party, where some contestation emerged. As attempts at divergence stemmed from the opposition party, it was not readily tolerated by the national government in control of the legal levers of power. All in all, South Africa's response to COVID-19 underscores that it is a hybrid federal state or, if you like, a unitary state with federal features. Its constitutional, financial, and political reality makes it prone to centralizing reflexes, even more so in times of crisis. The severe social, economic, and political difficulties the countries faced before the pandemic have been exacerbated by that pandemic. Whether the government will opt for a more 
differentiated approach to decentralization - where the capable do more, and the capacity-challenged subnational governments do less - to confront these challenges, is not likely. However, it may become possible when the government runs out of options for a way out of the crisis that the COVID-19 pandemic has deepened.

\section{Bibliography}

Department of Health, 2020. Update on Covid-19. July 31. Available from: https:// sacoronavirus.co.za/2020/07/31/update-on-Covid-19-31st-july-2020/ [Accessed 2 October 2020].

Department of Health, 2020. Update on Covid-19. December 31. Available from: https:// sacoronavirus.co.za/2020/12/31/update-on-covid-19-31st-december-2020/ [Accessed 20 January 2021].

De Visser, J. and Tinashe C., 2020. Municipalities and COVID-19: What the National Disaster Management Directions Mean for Municipal Governance. Local Government Bulletin, 15 (1). Available from: https://dullahomarinstitute.org.za/multilevel-govt/local-governmentbulletin/volume-15-issue-1-march-2020/municipalities-and-covid-19-what-the-nationaldisaster-management-directions-mean-for-municipal-governance [Accessed 10 January 2020].

Khumalo, B, Mahabir, J. and Dawood, G., 2015. South Africa's Intergovernmental Fiscal Relations System. In: Steytler, N. and Yash, P.G., eds. Kenya-South Africa Dialogue on Devolution. Cape Town: Juta, 201-226.

Medical Research Council (MRC), 2020. Report on Weekly Deaths in South Africa. December 31. Available from: https://www.samrc.ac.za/reports/report-weekly-deaths-south-africa [Accessed 20 January 2021].

Steytler, N., 2013. South Africa: The Reluctant Hybrid Federal State. In: Loughlin, J., Swenden, W. and Kincaid J., eds. The Routledge Handbook of Regionalism and Federalism. London and New York: Routledge, 442-454. 